\title{
Isolation of broadly neutralizing HIV-1 antibodies from high-throughput single B cell culture
}

\author{
NS Longo*, N Doria-Rose, K McKee, S O'Dell, MK Louder, Z Yang, R Bailer, JR Mascola \\ From AIDS Vaccine 2012 \\ Boston, MA, USA. 9-12 September 2012
}

\section{Background}

The isolation of broadly neutralizing HIV-1 antibodies that arise during infection has provided insights into the design of vaccine immunogens capable of eliciting similar antibody response. The use of HIV-specific sorting probes resulted in the isolation of antibodies to vulnerable viral epitopes, such as the CD4-binding site, but the use of such probes does not explore the subject's immunoglobulin repertoire breadth.

\section{Methods}

To identify new HIV-1 monoclonal antibodies (mAbs), we developed a B-cell culture system to isolate and screen thousands of B cells. Memory B cells were isolated by negative selection and individually cultured in 384 well plates with irradiated feeder cells expressing CD40 ligand. The addition of cytokines IL-2 and IL-21 stimulated proliferation and immunoglobulin secretion.

\section{Results}

After 14 days in culture, approximately $35 \%$ of the B cell clones secreted $>100 \mathrm{ng} / \mathrm{ul}$ of IgG which met the sensitivity threshold to screen each clone in an automated micro-neutralization assay. B cell clonal expansion allowed recovery of the immunoglobulin heavy and light chains by RT-PCR, with subsequent cloning into expression vectors and $\mathrm{mAb}$ testing against a large panel of viruses. In one experiment screening approximately 8600 B cells, 9 clones were identified as potential contributors to the neutralization detected in the patient's serum. One of the isolated clones produced mAb VRC22 with 30\% neutralization breadth and moderate potency. Further studies revealed that VRC22 was sensitive to JRCSF glycan mutants N332A and N301A but not N160K. VRC22 utilizes VH4-34 with a single amino acid CDR1 deletion

$\overline{\mathrm{NIH}}$, Vaccine Research Center, Bethesda, MD, USA and a mutation frequency of $7 \%$ which is a lower level of affinity maturation than observed for most known HIV-1 neutralizing antibodies.

\section{Conclusion}

This B-cell culture system allows efficient screening of thousands of individual B cells and the recovery of antigen specific mAbs. This approach can be used to isolate human mAbs to diverse pathogens.

Published: 13 September 2012

doi:10.1186/1742-4690-9-S2-P91

Cite this article as: Longo et al:: Isolation of broadly neutralizing HIV-1 antibodies from high-throughput single B cell culture. Retrovirology 2012 9(Suppl 2):P91.
Submit your next manuscript to BioMed Central and take full advantage of:

- Convenient online submission

- Thorough peer review

- No space constraints or color figure charges

- Immediate publication on acceptance

- Inclusion in PubMed, CAS, Scopus and Google Scholar

- Research which is freely available for redistribution 